\title{
CONTABILIDADE: ASPECTOS RELEVANTES DA EPOPÉIA DE SUA EVOLUÇÃO
}

\author{
SÉRGIO DE IUDÍCIBUS \\ Professor Emérito da FEA/USP \\ E-mail: siudicibus@osite.com.br \\ ELISEU MARTINS \\ Professor Titular do Depto. de Contabilidade e Atuária - FEA/USP \\ E-mail: emartins@usp.br

\section{NELSON CARVALHO} \\ Professor Doutor do Depto. de Contabilidade e Atuária - FEA/USP \\ E-mail: Inelson@usp.br
}

\section{RESUMO}

Trata o presente ensaio, como objetivo principal, de aspectos relevantes da epopéia da evolução da Contabilidade, através das várias fases históricas de seu desenvolvimento, desde o estado de simples método de escrituração baseado nas partidas dobradas até sua maturação como ciência social aplicada de forte fundo econômico. Ao longo do trabaIho são analisados os vários enfoques, abordagens e teorias, bem como circunstâncias históricas e outras que possam explicar a Contabilidade enquanto ciência genuinamente social.

$\mathrm{Na}$ interpretação mais atualizada dessa disciplina, a cientificidade contábil deve ser procurada, preferencialmente, numa série de características como, por exemplo: no entendimento e mensuração aplicados aos elementos do patrimônio; na preponderância do valor econômico em lugar de simples custos ou preços; no caráter preditivo das demonstrações contábeis; na introdução do fator risco e do conceito do valor do dinheiro no tempo nas avaliações contábeis, bem como na consideração de custos imputados e de oportunidade etc. A Contabilidade pontifica pela observação das características anteriormente vistas e pela incorporação, em seu arcabouço conceitual, da premissa da prevalência da essência sobre a forma, no campo do conhecimento social aplicado, de natureza econômico-financeira, com ramificações nas áreas de produtividade, ambiental e social e com evidentes conotações quantitativas quanto à sua mecânica patrimonial.

\section{ABSTRACT}

As a main objective, this paper aims at discussing relevant aspects in the epopee of accounting evolution through several historical stages, from a simple method of bookkeeping based on double entry until its ripening as a social science with a strong economic basis. Some views and approaches to the concept of accounting will be revisited, as well as theories and the historical circumstances and other factors that may explain accounting as a genuine social science.

In the more advanced interpretation of our discipline, the scientific quality of accounting should be searched preferentially in a series of characteristics, such as, for example: the understanding and measuring of equity elements; the preponderant application of economic value rather than simple costs or prices; the predictive power of financial statements; the introduction of the risk factor and time value of money in accounting evaluations, as well as the consideration of imputed costs and of opportunity costs. The relevance of accounting stems from the observation of the above-mentioned key issues as well as by the incorporation of the prevalence of essence over form into its conceptual framework, in the field of socially applied knowledge area of an economic-financial nature, with ramifications in the areas of productivity, environment protection and social responsibility, with necessary quantitative features as to its mechanics of functioning.

It is evident that, for research purposes and to enhance certain dimensions, accounting may be 
É claro que, para efeito de pesquisa e para realçar certas dimensões, a Contabilidade pode ser estudada sob as mais variadas ênfases, como a ética, a macroeconômica, a institucional e social, a comportamental, a sistêmica e a histórica, entre outras, só que a Contabilidade é muito mais que qualquer dessas suas abordagens individualmente tomadas. No fundo, um dos objetivos deste trabalho é, também, subsidiariamente, o de ajudar a responder, pelo menos em parte, à pergunta cuja resposta se apresenta quase como um enigma: afinal, o que é a Contabilidade?

Palavras-chave: Contabilidade; Epopéia; Evolução Histórica; Abordagens; Cientificidade; Teorias; Valor. studied under a variety of approaches, such as the ethical, the macroeconomic, the institutional and social, the behavioral, the systemic and the historical, among others, but accounting is much more than any of its particular approaches. Finally, one subsidiary objective of this paper is to help trying to answer, at least partially, on the question which addresses to almost an enigma: after all, what is accounting?

Keywords: Accounting; Epopee; Historical Evolution; Approaches; Scientific Quality; Theories; Value.

\section{INTRODUÇÃO}

A Contabilidade, campo de conhecimento essencial para a formação dos agentes decisórios dos mais variados níveis, é fruto concebido da relação entre o desenrolar dos fatos econômico-financeiros e sua captação e processamento segundo os paradigmas de uma metodologia própria e potencializada pela racionalidade científica. Logo, a pedra fundamental que apóia e sustenta o edifício contábil pode ser definida como "a contabilidade seguindo, relatando e respeitando a essência dos eventos econômicos que captura e mede".

A capacidade de capturar, primeiro, a ocorrência dos eventos econômicos que impactam em um determinado estado de riqueza, depois a de precificá-lo e, por último, de comunicar seus efeitos, é o desafio a que a Contabilidade está, não apenas preferencialmente, mas de fato unicamente, habilitada a enfrentar, apoiando-se sempre em disciplinas afins dentre as quais o Direito, a Economia, os Métodos Quantitativos e a Ciência da Informação.

A doutrina contábil é a face científica desse encontro fértil entre a realidade e o modelo para acolhê-la e descrevê-la. Do lento, mas maravilhoso crescimento multiforme, nascem, primeiramente, a escrituração e, mais tarde, a ciência contábil e, portanto, sua doutrina.

O irromper das questões práticas, que devem ser resolvidas a fim de a Contabilidade ter sua função na vida real das organizações e das entidades, de forma alguma pode perturbar, mas sim potencializar, as especulações teóricas enquanto ciência. Não se pode esquecer que a Contabilidade, genuína e amplamente explicada por teorias de caráter científico, tem sua faceta prática, extremamente importante, que é a de servir como instrumento de accountability, de avaliação da entidade e de seus gestores, da prestação de contas destes e como insumo básico para a tomada de decisões dos agentes econômicos, tanto internos quanto externos à entidade. Talvez, seu caráter científico, na verdade, repouse exatamente no entrelaçamento harmônico e conceitual de seus objetivos, acima delineados, e não em visionárias concepções fundadas no vazio de uma lógica formal fria, infértil e privada de conseqüências.

A urgência na procura de modelos que sirvam para a solução de problemas reais só pode acelerar o desenvolvimento da Contabilidade. Na verdade, as técnicas são os braços, no mundo real, das doutrinas, da mesma forma que o desenvolvimento tecnológico é a conseqüência da pesquisa pura.

Há os que se comprazem em fazer recair suas concepções teóricas num mundo abstrato e distante da realidade, de uma ciência que a si se basta, sem se lembrarem que essa disciplina nasceu das necessidades prementes de gestores, comerciantes, banqueiros, agentes econômicos de maneira geral, à procura de um modelo descritivo, primeiramente, e, com sua evolução, previsional, para o mundo dos negócios. E sem se lembrar que a validação de qualquer teoria contábil se dá única e exclusivamente pela sua utilidade gerada perante os usuários no mundo prático.

Hendriksen e Van Breda (1999:39) pontificam:

[...] A contabilidade é um produto do Renascimento Italiano. As forças que conduziram a essa renovação do espírito humano foram as mesmas que criaram a contabilidade $[\ldots]$

$\mathrm{Na}$ verdade, os autores acima se referem à Contabilidade como hoje a conhecemos (como 
sistema de escrituração e posteriormente de informação), pois suas formas mais rudimentares já se evidenciavam há muito mais tempo.

Mas, que forças foram essas a não ser a conjugação de espiritualidade e racionalidade casadas com a vibrante atividade comercial das cidades do norte da Itália, como Gênova, Veneza, Pisa e Florença, entre outras?

Claramente, a contabilidade, antes de ciência, foi, em seus inícios, um sistema completo de escrituração. O método das partidas dobradas, base do sistema, encontra seus registros iniciais já em 12991300 em uma empresa de mercadores de Florença e uma forma mais completa, em 1340, na cidade de Gênova.

Está-se a falar, ainda, de sistema de escrituração e de método das partidas dobradas. Por enquanto, naquelas antigas eras, eram sinônimos de contabilidade. Faltava muito, entretanto, para o nascimento da ciência da contabilidade.

Fica, assim, bem patente, desde seu "renascimento" como sistema perfeitamente desenvolvido, que a contabilidade da época era a resposta às necessidades práticas dada pela criatividade do ser humano em desenvolver técnicas para resolver problemas reais.

\section{UMA GESTAÇÃO DE RISCO}

A Contabilidade, como sistema de escrituração e como hoje a conhecemos, surgiu através da interação e integração de grande número de eventos, fatores históricos, com a participação de várias civilizações e vários povos. Apesar de seu desabrochar formal ter-se dado na Itália da Renascença, como se viu, as sementes de sua gestação são as mais variadas. Fenícios, Persas, Egípcios, Gregos, os antigos habitantes do hodierno Iraque, Romanos etc., todos são importantes para explicar os antecedentes da Contabilidade, antes da Renascença Italiana.

Entretanto, uma influência predominante e persistente deve-se aos Árabes, de maneira geral, a partir do século VII, influenciados pelos Indianos. O conceito do zero e toda a lógica aritmética e algébrica, bem como o sistema numérico arábico, são fundamentais nessa evolução. Imagine como seria difícil somar, multiplicar e dividir com o sistema Romano! Os comerciantes, matemáticos e aventureiros europeus aprenderam muito com os Árabes. Um dos mais conhecidos desses europeus, Leonardo Fibonacci, trouxe para o continente europeu as experiências e os conhecimentos adquiridos com os árabes, escrevendo, em 1202, o Liber Abaci, um precursor dos livros de escrituração que adviriam mais tarde, a partir, principalmente, da obra de Luca
Pacioli. O Liber Abaci também popularizou o sistema numérico arábico na Europa.

Hendriksen e Van Breda (1999), também, ressaltam a importância da invenção de uma vela triangular, a vela latina, que facilitou, por suas características técnicas, a era dos descobrimentos, muito importante para o florescer da escrituração.

O próprio trabalho de Pacioli enquadra, perfeitamente, o método contábil como um dos capítulos de um livro de aritmética, geometria e álgebra. Não se sabe muito bem quem "inventou" o método das partidas dobradas, mas não há dúvidas de que $\mathrm{Pa}$ cioli lhe emprestou um significado eminentemente matemático. As explicações posteriores, tanto do Personalismo, quanto do caráter eventualmente dialético da antítese entre débito e crédito e muitas outras são, até, interessantes, mas, ao ver dos autores deste ensaio, não destituem o método de sua essência quantitativa.

Ressalte-se também que, à época do surgimento das partidas dobradas e, crê-se, até na época de Pacioli, possivelmente não se conhecia, ainda, o conceito de número negativo. Daí, por incrível que possa parecer, haver surgido uma das maiores forças do método, representado pela figura da dualidade débito/crédito, ou seja, os escrituradores da época desenvolveram, a seu modo, uma espécie de nova teoria matemática com a figura do saldo devedor e credor para suprir o que faltava. Entre outras, surgiu daí, inclusive, a conseqüência seguinte: se for debitada uma conta representativa de um ativo, por exemplo, quando esse, por outra operação, diminui, não se registra como número negativo ou dedução do lançamento anterior no lado do débito, mas sim como crédito, no lado direito, permanecendo ambos os registros, bem como valendo seu resultado algébrico (o saldo). E esse saldo, "devedor" ou "credor" não chocava o conhecimento da época que ainda não aceitava a existência de valores negativos para representação de qualquer coisa concreta (como as dívidas, ou as despesas, por exemplo). Geniais esses criativos escrituradores. Uma verdadeira epopéia essa conquista!

Se quase não mais existem dúvidas de que as partidas dobradas foram utilizadas já no Século XIII, a pergunta que se pode formular é: quais teriam sido os motivos que fizeram com que não tivessem aparecido antes, nas civilizações mais antigas, já que sinais de registros contábeis primitivos, na forma de contagens e inventários, já existiam? Provavelmente, a melhor explicação tenha sido a dada por Littleton, citado por Kam (1990). Segundo aquele autor, é lógico supor-se que as partidas dobradas tivessem surgido quando de fato surgiram devido à existência de certas condições plenas 
que não estiveram presentes nas civilizações mais antigas, como condições materiais e de linguagem (comunicação). Nas civilizações mais antigas, tais condições, embora presentes, não tinham, segundo Littleton, a "energia" suficiente para provocar a mudança. Mais adiante, o próprio Kam (1990) explica melhor o conceito, afirmando, textualmente, em tradução livre (página 2):

[...] As explicações que avançamos aqui é que a força primária para o desenvolvimento da contabilidade a partidas dobradas é a formação e o crescimento das entidades empresariais num ambiente de mercado complexo. Primeiro, existe a motivação inicial que impele as pessoas a procurar lucros para si, que denominaremos de espírito capitalista. Segundo, certos eventos econômicos e políticos criam as condições às quais as entidades respondem. Terceiro, certas inovações tecnológicas provêm o estímulo para a formação e o crescimento das entidades comerciais. Essas três razões para o desenvolvimento das organizações, que por sua vez resultam no desenvolvimento das partidas dobradas, podem ser denominadas de forças sociais [...].

A pergunta que Kam formula à página 33 da obra citada é contundente, plena de dúvidas e incertezas, bem como de indagações, e ainda não completamente respondida. Dramaticamente, questiona: 0 que é Contabilidade? Certamente, não se haverá de ter, neste ensaio, a pretensão da explicação cabal, mas procurar-se-á, através da exploração de argumentos históricos, lógicos e derivantes da observação, tentar reconstituir o caminho, a evolução havida até o presente e indicar as tendências futuras. A maioria dos autores procura definir o que é, pelo que ela faz e realiza, mas tal definição peca por restringir as potencialidades desse campo de conhecimento. De qualquer forma, do que foi tratado até aqui, ressalta, clara e cristalina, a ligação entre as necessidades prementes derivantes da atividade econômica e o desenvolvimento de respostas contábeis. Certamente, só isso não caracteriza uma ciência. A ciência deve ser capaz de estabelecer relações entre causas e efeitos, além de dar ao campo de conhecimento e ao universo de eventos nele contido um amplo guarda-chuva conceitual. Mas, é inegável a grande intimidade entre os incentivos e problemas derivantes da atividade econômica desenvolvida pelas entidades e as técnicas contábeis imaginadas para resolver ou equacionar tais problemas e anseios. Em nada diminui a nobreza dessa disciplina revelar seu caráter eminentemente utilitarista.

\section{CONTABILIDADE: NASCEU GERENCIAL OU FINANCEIRA?}

Questão que poucos discutem, uma exceção notável sendo a linha de defesa da genética gerencial apresentada em palestras, discussões e artigos por Eliseu Martins (1988; 2005), um dos autores do presente ensaio. É importante, para entender a evolução da disciplina, perpassar as várias fases de seu desenvolvimento. Essas fases se alinham ao surgimento dos vários "interessados" - ou stakeholders - na informação contábil.

Sem dúvida, o que se conhece da evolução da Contabilidade, primeiro como sistema de escrituração, evoluindo, lentamente, para o estado de ciência, faz meditar que o impulso inicial para seu surgimento tenha sido (1) de natureza sócio-econômica ampla, ou seja, o surgimento, conforme Kam, já citado, do "espírito capitalista", espírito esse que se traduzia em necessidades prementes de acompanhar a evolução da riqueza patrimonial das entidades, a partir, principalmente, do Século XII, fortalecendo-se no XIII (já com as partidas dobradas) indo até inícios do Século XIX, aperfeiçoandose em suas técnicas escriturais. Praticamente, é no século XIX que a Contabilidade, através de autores talentosos de vários países, não sem predecessores em épocas anteriores, assume vestimenta científica, saindo do estreito âmbito da escrituração para as especulações sobre avaliação, enquadramento da Contabilidade entre as ciências, introdução dos raciocínios sobre custos de oportunidade, riscos e juros etc; (2) uma vez constituída a entidade, era necessário, portanto, seguir a evolução de seu patrimônio. Claramente, como ainda era vaga ou inexistente, no alvorecer da contabilidade, a noção de separação entre proprietário e gerente ou administrador da entidade, inclusive, via de regra, com exceções, devido à menor dimensão dos empreendimentos, o proprietário era, também, gerente da entidade. Parece proceder, assim, o pensamento do referido professor.

Adicionalmente, cumpre revisitar a postura do Estado em face da Contabilidade para analisar sua evolução. É imperativo encarar como interessado ou stakeholder natural, o Estado, com seu poder de arrecadar tributos. Mas, para isso, ou para esse stakeholder privilegiado, a contabilidade sempre se denodou em apresentar soluções e atenção especial. No entanto, embora seja inegavelmente nobre a função arrecadadora do Estado para que possa cumprir o mandato que a Sociedade lhe confere, há que se seguir contestando e refutando o excesso de intromissão governamental determinando à contabilidade práticas, métodos e regras que, para atingir o objeti- 
vo admitido - computar a base de arrecadação - resvale ferindo objetivos que não lhe são próprios, como a medição do desempenho empresarial na ótica do sócio ou do credor. O ramo tributário do leque de especializações contábeis não deve ter o direito de conspurcar outros ramos, como o da Contabilidade dita Financeira ou Societária, por exemplo.

À medida que foram aparecendo, como conseqüência da evolução dos tempos e das organizações, os outros "players", a Contabilidade foi se transformando, aos poucos, de um engenhoso sistema de escrituração e demonstrações contábeis simplificadas, num complexo sistema de informação e avaliação, com características científicas, institucionais e sociais de grande relevo e tendo, como objetivo central, suprir a necessidade informacional de seus usuários internos e externos à entidade a que se refere.

Um dos motivos que provocaram mudança substancial no escopo e complexidade da contabilidade foi, sem dúvida, o surgimento do gestor ou gerente como agente separado do proprietário, principalmente a partir de final do século XVIII, avolumando-se essa tendência no século $X X$, com as grandes sociedades por ações.

A dicotomia de interesses e objetivos de proprietários e gerentes (esses últimos também pertencem a outro subgrupo, o dos funcionários da entidade), embora, por definição, os administradores devessem gerir por conta e em benefício dos donos do capital, levou a evoluções extraordinárias, na Contabilidade. Uma delas, o (re)nascimento da Contabilidade Gerencial como subárea específica de interesse e de estudo. Apesar de a Contabilidade ter nascido gerencial quanto ao interesse do proprietário (pois dono e gerente eram a mesma pessoa), foi somente a partir da separação que a Contabilidade Gerencial, filha extraída de uma costela da Contabilidade Geral, se expande, se desvincula dos rígidos parâmetros da Financeira (voltada aos usuários externos e, entre nós, conhecida por Societária) e cria vida própria, principalmente a partir da segunda metade do século XX, sendo o trabalho de Anthony (1966) um dos precursores no gênero.

A dicotomia de interesses aparece porque gerentes e proprietários, no pressuposto da teoria do comportamento racional dos agentes econômicos, procuram maximizar suas satisfações. Embora os gerentes, em princípio, trabalhem para os proprietários, eles acabam criando suas motivações pessoais, seus objetivos de maximização de satisfação que nem sempre coincidem com os dos proprietários. Para modelar essa dicotomia de interesses e objetivos, tentando a convergência possível, surge, na terceira parte do século XX, a Teoria da Agência.
Em Economia (hoje em seu ramo denominado de Institucional), Jensen e Meckling (1976), no que se refere à proposta para reduzir custos contratuais, escrevem trabalho pioneiro.

No que se refere a essa teoria, especificamente o aspecto da assimetria informacional é apenas um dos resultantes da dicotomia entre proprietários e gerentes e parte da premissa de que, internamente à empresa, os gerentes (chamados de agentes na Teoria) dispõem de muito mais informação do que os proprietários (chamados de Principais). Da mesma forma, como a sociedade em geral é uma rede de contratos de agência, se for considerada a empresa em relação ao mercado, esse tem menos informações do que aquela. Diminuir ou conter a assimetria informacional é uma das tarefas mais importantes da moderna Contabilidade, agora sim, nesse aspecto (e em outros, como se verá mais adiante), já atingindo a estatura de ciência. Com relação aos aspectos do surgimento da Teoria Positiva, com os trabalhos pioneiros de Ball e Brown (1968), de Beaver (1968) e muitos outros, constituem linhagem distinta de pesquisa, diferente da Teoria da Agência a qual, embora em sua modelagem mais avançada seja expressa em formulações quantitativas, é um modelo analítico e não um teste de hipóteses, uma das premissas da pura teoria positiva. Voltar-se-á a discorrer sobre essa última, brevemente, mais adiante. No que se refere à Teoria da Agência, em sua apresentação mais formal, não se podem esquecer as contribuições de Jennergren (1980), Wilson (1968), Ross (1973), Demski (1976) e muitos outros. Vê-se, assim, uma plêiade de outros inovadores a ousar e se arriscar nessa epopéica evolução.

Finalizando este tópico, depreende-se que o que se informa, em Contabilidade, e como, é algo extremamente importante. Assim, quando uma empresa, sem levar em conta seus aspectos operacionais intrínsecos, simplesmente adota, no cálculo da depreciação, uma taxa linear de $10 \%$ ao ano (a taxa fiscalmente admitida para fins de dedutibilidade), e assim informa ao mercado, sendo que, por suas características operacionais, a taxa correta deveria ser outra, estará, simplesmente, aumentando a assimetria informacional do mercado em relação à empresa. Sob a fácil égide da padronização fiscal, pode-se estar levando os agentes a uma visualização errônea da situação da empresa. (Ver IUDíClBUS e BROEDEL, 2002).

\section{OBJETO E OBJETIVOS}

Até o item anterior, discutiram-se vários aspectos da evolução histórica e da genética contábil. O entrelaçamento entre o que se pretende alcançar 
em Contabilidade e o contexto patrimonial dentro do qual se desenvolvem os efeitos dos eventos que são registrados deixa não muito clara, às vezes, a diferença entre objeto e objetivos da Contabilidade.

$\mathrm{Na}$ visão destes ensaístas, os objetivos têm um alcance e uma hierarquia muito mais amplos do que o objeto. Objetivo é onde se quer chegar e quem se quer encontrar; objeto representa o contexto formal da estrutura patrimonial que se altera à medida que os eventos são captados e registrados pela técnica contábil.

Suponha-se, assim, que o objetivo da Contabilidade seja o de transmitir, de forma inteligível e inteligente, informação estruturada de natureza econômico-financeira, física, de produtividade e social aos vários grupos de usuários da informação contábil, para sua avaliação e decisões informadas, conforme a definição da Estrutura Conceitual Básica da Contabilidade da CVM ${ }^{1}$, ligeiramente adaptada: conquanto se possam discutir variantes, no que se refere aos objetivos, poucos contestarão a definição. Surge, agora, a questão: será que a forma como a Contabilidade, em sua função de sistema receptor, processador e transmissor dos resultados de eventos e transações, obtém essas informações seria a única viável ou possível? Parece que não, pois se poderia, através de outro sistema ou até mediante outra técnica que não a contábil, transmitir aos usuários informações de natureza tal que, de alguma forma, suprissem as necessidades dos usuários. Apresentando outro exemplo e analogia, suponha-se que o objetivo seja o de se chegar a um determinado destino: poder-se-ia chegar de avião, de automóvel ou até andando. Variarão o tempo, o custo, o conforto, a segurança, mas o objetivo final poderá ser alcançado por qualquer forma.

Objetivo e objeto, todavia, estão intimamente ligados em Contabilidade. A natureza única e distinta da Contabilidade, como técnica e ciência, é a ligação entre objetivos (o quê fazer, aonde chegar) e o objeto (a estrutura viária (patrimonial) que levará a alcançar o objetivo).

Por estranho que possa parecer, talvez o fato de os objetivos poderem ser atingidos, pelo menos em parte, através de outro campo de conhecimento, que não o estritamente contábil, realce a força do modelo contábil e da integração entre objeto e objetivo. Só a Contabilidade consegue atingir os objetivos propostos, de forma sistemática e com uma relação custo/benefício favorável, através de sua técnica formal de captação, registro, acumu- lação e comunicação de informações contábeis. Assim, o objeto da Contabilidade, ou seja, o patrimônio e suas variações quantitativas e qualitativas, é a resposta ou a forma mais inteligente, conforme a aceitação da própria sociedade (pois, se assim não fora, ela teria se casado com outro parceiro), de se atingirem os objetivos. Note-se, todavia, que, antes de se atingirem os objetivos, é preciso um processo de comunicação claro no qual o usuário perceba com nitidez o que a linguagem contábil quer transmitir. Essa última parte do processo está longe, ainda, de ter sido resolvida eficientemente, pois envolve transmissor e receptor, ruídos de informação, capacidades distintas de absorção do significado da informação transmitida etc. Está a desenvolver-se, nos últimos decênios, o estudo da Semiótica Contábil, parte aplicada da Teoria da Comunicação, com resultados prometedores, mas ainda incipientes. Por outro lado, não existem pesquisas conclusivas apontando que efeito se teria na qualidade das decisões por parte dos usuários, se, em vez da Contabilidade, outra fosse a fonte de informação econômico-financeira sistemática. Notese, todavia, que os usuários não se utilizam apenas da informação contábil para suas avaliações e decisões, atualmente.

O objetivo nasce da necessidade dos usuários. O objeto, o patrimônio, é a grande resposta contábil. O núcleo através do qual, se o contador for além da mera equação patrimonial histórica, se contemplar os desafios do valor em lugar do custo, introduzindo as noções de custos imputados e econômicos, de custo de oportunidade, de valor do dinheiro no tempo, aprofundando a análise dos elementos patrimoniais pelo seu Value at Risk e pela pluralidade dos resultados possíveis em face da variabilidade das premissas subjetivas inerentes, terá construído um modelo de validade científica comprovada, único, como avaliador do desempenho de uma entidade. Note-se que alguns autores, como Broedel Lopes (2002), consideram que o patrimônio não pode ser o tecido científico da Contabilidade, pois quem define patrimônio é a própria contabilidade. Isso faria recair o campo dos eventos a serem estudados pela ciência contábil, efetivamente, no estudo da informação, ligado aos objetivos, e não no patrimônio, propriamente. Na verdade, como foi visto, o patrimônio é a forma primária (o acompanhamento de sua evolução no tempo) que a Contabilidade escolheu para iniciar o processo de geração de informações úteis para os usuários.

${ }^{1}$ Deliberação CVM no 29/86, que aprovou esse Pronunciamento do IBRACON - Instituto dos Auditores Independentes do Brasil e o tornou obrigatório no âmbito das 


\section{BIOLOGIA, EMBRIOLOGIA E MORFOLOGIA DA CONTABILIDADE}

A Contabilidade pode ser estudada em analogia com o estudo dos seres vivos. Em seus aspectos biológicos, estudam-se as manifestações vitais da Contabilidade, bem como seu relacionamento com o mundo que a cerca. Em seus aspectos embriológicos, estuda-se o fenômeno da transformação de um estado para outro. E, em sua morfologia, analisam-se as medidas classificatórias e os indicadores extraídos das demonstrações contábeis. $O$ todo deve servir como uma explicação para a teoria da evolução dessa disciplina. Usualmente, os estudiosos da matéria limitam-se aos aspectos morfológicos. Mas, a observação interligada dos três estados é extremamente importante para caracterizar a evolução da espécie contábil.

As demonstrações da vivência e existência da Contabilidade e seus relacionamentos com o mundo que a cerca podem ser inferidas de várias formas: a mais importante é a paleontologia contábil, ou seja, o estudo dos arquivos históricos e dos signos pictóricos e numéricos deixados pelos contadores de antanho, de várias civilizações, para se avaliar como atuava e como se relacionava em cada época histórica. Sua evidenciação atual, também, é extremamente importante, mas deve ser encarada como um estágio da evolução, nunca como final. Percebe-se que a Contabilidade esteve presente na vida das sociedades, das mais variadas formas, desde as mais remotas eras, que remontam, aproximadamente, às civilizações: mesopotâmica, egípcia, fenícia, grega, romana e de todos os povos da Antiguidade, evoluindo continuamente, passando pela fase da Renascença, pela Revolução Industrial, até chegar à Era do Conhecimento e da Informação. Como já se viu, em tópico anterior, a Contabilidade, à semelhança dos seres vivos, evolui lenta mas seguramente através dos séculos (às vezes com saltos heróicos, como em todas as ciências), passando pela fase embrionária, de 6.000 anos antes de Cristo até, aproximadamente, 2.000 anos antes de Cristo, em que era um rudimentar instrumento pictográfico e numérico para inventariar bens, direitos e obrigações. Com as civilizações clássicas já em plena maturidade, como a Egípcia e outras, mais tarde a Grega e a Romana, de 800 a.C. até o século XIII, passando pela longa noite da Idade Média, continua aperfeiçoando sua evolução, através de documentos contábeis estáticos, de posição patrimonial cada vez mais avançada, até se chegar à invenção do método das partidas dobradas e da Contabilidade como técnica completa de escrituração e de emissão de demonstrações contábeis, como já se analisou, por volta do século XIII, até a sistematização definitiva por Pacioli.

A embriologia contábil é muito importante no contexto evolutivo, pois explica como certas espécies contábeis evoluem, aparentemente, para outras, guardando, porém, algumas características do embrião inicial. Assim, a Contabilidade, que nasceu para finalidade gerencial, mas sob a forma de Contabilidade Financeira, apresenta uma mutação e se transforma, mais tarde, em Contabilidade Gerencial, entre outras espécies derivadas. $\mathrm{Na}$ verdade, a essência da Contabilidade Financeira faz parte da genética inicial da Contabilidade Gerencial. Por isso que uma verdadeira teoria da contabilidade não poderia deixar de tratar da contabilidade gerencial. Grande parte dos autores não atacou de frente esse problema pelo receio de amarrar a gerencial à fogueira punitiva e implacável dos princípios fundamentais de Contabilidade, aparentemente inibidores. Não se concorda com essa visão pois, se os princípios de fato existirem e se forem definidos de forma mais ampla, com aceitação de valor em lugar de preços, de custos imputados, de oportunidade etc., é perfeitamente possível enquadrar as práticas da Contabilidade Gerencial sob um amplo guardachuva conceitual teórico.

A morfologia contábil estabelece as medidas e classificações das espécies e sub-espécies. Assim, as sub-espécies poderiam ser a Contabilidade Gerencial, a de Custos, a Estratégica (essa, por sua vez, uma sub-espécie da gerencial), a Auditoria, as revisões e as perícias etc. Dentro de cada subespécie existem classificações específicas, bem como medidas e indicadores especiais que se atêm às características da sub-espécie, embora alguns indicadores sejam comuns a todas, como Lucro sobre Patrimônio Líquido, Lucro Operacional sobre Ativo Total e poucos outros. A morfologia contábil é importante no processo evolutivo pois caracteriza e monitora a evolução das espécies contábeis dando condições aos pesquisadores de proteger as em extinção, se necessário.

\section{AS VÁRIAS ABORDAGENS À CONTABILIDADE}

A Contabilidade pode ser visualizada conforme várias abordagens, enfoques, o "approach" dos povos de língua inglesa. Conquanto nenhuma das várias abordagens seja suficientemente ampla e densa para explicar toda a prática contábil, elas lançam luzes e fazem vislumbrar aspectos interessantes e peculiares.

Não se tratará, neste trabalho, de todas as principais abordagens, nem mesmo da maior par- 
te delas, pois estão devidamente tratadas nos textos de Hendriksen e Van Breda (1999) e ludícibus (2004). Apenas, invadir-se-á o âmago de algumas delas, sob alguns aspectos que melhor explicam a evolução da espécie contábil.

Assim, à luz da moderna teoria positiva da Contabilidade, alguns conceitos, princípios e abordagens podem ser questionados. A abordagem ética, nesse sentido, pode ser objeto de contestação, pois, no pano de fundo das pesquisas sobre mercado de capitais, o fato de os agentes econômicos sempre procurarem o melhor para si, em termos econômicos, não deixa muita margem para valores como ética, justiça, distribuição social e outros. Cada um age de acordo com o que é melhor para sua situação econômica. Como disciplina eminentemente social, todavia, a Contabilidade não pode ser imoral ou privilegiar, em prejuízo de outros, certos stakeholders. Veja que se disse [...] em prejuízo de outros. Isso significa que não se pode aumentar a assimetria informacional que existe entre os conhecedores da situação da empresa (os agentes internos) e os outros. Não impede que certos agentes possam ter um grau de detalhe de informação maior do que outros, de acordo com as necessidades de seu modelo decisório. Desde que os outros tenham o mínimo necessário para poder fazer inferências com relação à entidade. Essa situação é bastante delicada e os limites entre o comportamento hedonista, de um lado, e a inobservância de regras de eqüidade, de outro, são muito tênues. Assim, a denominada abordagem ética da Contabilidade permanece quase que como um santuário de propósitos, uma promessa que se faz, da mesma forma que os crentes procedem com relação a Deus, ou seja, de não pecar, de comportar-se com justiça e retidão, de não prejudicar ninguém. É claro que o mundo real da competitividade provoca outros comportamentos. Mas não se pode, socialmente, desistir de se procurar um comportamento ético, como entidade inserida num contexto social. Claramente, não se deve, nunca, extravasar para o que não se possa caracterizar como legal. Ético, justo e legal é o comportamento ideal. O obtido, muitas vezes, é apenas o legal.

A Abordagem Fiscal, tratada por Hendriksen e Van Breda, tem descaracterizado, principalmente em muitos paises de origem ibérica e germânica, as aplicações mais nobres da Contabilidade. Entretanto, isso se deve à exagerada influência do Fisco na utilização de critérios dentro do regime de competência. No Brasil, por exemplo, quase nenhuma empresa se preocupa em calcular da forma mais correta possível as taxas de depreciação a serem aplicadas a seus ativos depreciáveis. Via de regra, utiliza-se a porcentagem aceita para fins de dedutibilidade pelo Fisco. Como se viu, longe de padronizar, essa prática aumenta a assimetria informacional entre empresa e mercado. Embora a Lei das S/A tenha tentado separar Contabilidade Fiscal da Societária $^{2}$, a influência fiscal é assombrosa e reflete, também, um certo grau de comodismo e conformismo dos contadores, muito típicos da tradição emanada do direito romano-germânico. Na verdade, a Lei, no caso, permite a utilização de outras taxas na Contabilidade Societária, mas a tradição legal é tão forte que os contadores não se utilizam da prerrogativa. $\mathrm{O}$ tratamento contábil que ainda se dá às operações de arrendamento mercantil financeiro (apesar da tímida, mas louvável investida do ConseIho Federal de Contabilidade sobre o assunto - não seguida na prática), ao "sale-lease-back", a muitos provisionamentos (quando não dedutíveis, é claro), às subvenções para investimento (em desacordo com as práticas mundiais), às vendas (com base, comumente, nas emissões de notas fiscais e não no momento econômico em que a receita é "ganha" ou auferida pelo agente ou entidade, principalmente no caso dos serviços) etc. são alguns dos exemplos dessa preponderância das regras fiscais sobre as informações econômicas que deveriam estar efetivamente refletidas nas demonstrações contábeis.

Inadequação da Abordagem Macroeconômica: Freqüentemente apontada como inteligente e sofisticada, essa abordagem, se utilizada, subjuga os critérios de apropriação contábil, principalmente no que se refere à utilização dos provisionamentos, dedutibilidade ou não de gastos para efeitos tributários etc. à política macroeconômica de um país, visando servir como ação anticiclo. A mais conhecida, mas não única diretriz, nesse sentido, é a prática da depreciação acelerada contábil para efeito de incentivar investimentos em equipamentos a fim de estimular a atividade econômica. Conquanto útil em circunstâncias especiais ou para setores definidos, a prática generalizada da contabilidade a serviço da macroeconomia é totalmente inadequada à luz da verdadeira função da Contabilidade. De forma alguma se servirá bem à sociedade obedecendo a critérios mutáveis de políticas econômicas ditadas por equipes econômicas, às vezes, de duvidosa capacidade técnica. A sociedade será muito mais bem servida se a contabilidade apurar o resultado econômico mais correto possível, à luz da melhor técnica de que se possa dispor, do que perseguir um resultado desejado. Nesse aspecto, estar-se-ia a 
manipular a Contabilidade pior ainda do que se faz, às vezes, no gerenciamento de resultados, pelos gerentes da entidade. Estes, pelo menos, conhecem sua empresa. A boa alocação de recursos na economia estará muito mais amparada, crê-se, com uma Contabilidade correta, executada por milhares de entidades, do que por uma rígida padronização de práticas contábeis a serviço de autocracias, mesmo que competentes, nunca o suficiente para substituir o mercado. A denominada contabilidade macroeconômica (ou abordagem macroeconômica) é, assim, totalmente condenável numa economia de mercado. A Contabilidade é muito útil, como resultado das ações tomadas pelos agentes em função das informações por ela prestadas, à macroeconomia, mas não pode ser induzida, em suas normas, por ditames macroeconômicos, a não ser em casos excepcionais e por curto lapso de tempo. No Brasil, felizmente, essa abordagem normalmente não afeta tanto a Contabilidade como em outros países no caso das depreciações, já que os incentivos fiscais que têm existido com esse fim têm sido controlados extra-contabilmente, no livro de apuração do lucro tributável - conhecido como Lalur; mas as seguidas investidas nos diferimentos de variações cambiais com a tecnicamente insustentável desculpa de não se quebrar regras contratuais de relação capital próprio/de terceiros, ou para se continuar a distribuir dividendos onde lucros podem até inexistir são exemplos infelizmente presentes.

Continuando com a análise crítica das várias abordagens, exemplo de uma que se apresenta como desafiadora é a que se poderia denominar de Abordagem Social e Institucional, mais freqüentemente referida como Social ou Sociológica. Nesta resenha, realçam-se as características institucionais, pois confunde-se, muitas vezes, abordagem social com balanço social, forma de evidenciação contábil para stakeholders específicos, como empregados da entidade, aspectos ambientais e de extensão de serviços à comunidade. No Brasil, tem estado bastante em evidência, nos anos mais recentes, essa abordagem entendida em seu sentido mais restrito. Apesar de notáveis trabalhos, como o de Tinoco (2001) e alguns outros como Ribeiro (1992; 1998), Antunes (1999) e de algumas empresas terem empreendido sérios esforços para elaborar um balanço social significativo, boa parte das evidenciações atêm-se mais a aspectos de promoção institucional das entidades do que a verdadeiros e fidedignos reportes sociais. De todas as sub-espécies do balanço social, sem dúvida, a faceta ambiental, para estes autores, representa a interface mais interessante e que, provavelmente, se desenvolva bastante no futuro, sem desmerecer as demais, como a laborial e a Demonstração de Valor Adicionado, bem como a comunicação de serviços prestados à sociedade em geral. A abordagem social, todavia, poderia ser considerada com um espectro mais amplo, como o de abranger demonstrações contábeis de resultados sociais, como no caso de uma Universidade, por exemplo, em que, num sentido social amplo, sua receita social seria muito maior do que o valor das anuidades e contribuições recebidas, para abraçar o valor social no mercado dos que vierem a se formar na dita Universidade. Essa sub-espécie de abordagem social, todavia, conquanto atrativa, não tem prosperado, pelas evidentes dificuldades de mensuração e devido a seu exagerado subjetivismo. Mais recentemente, têm-se desenvolvido estudos na área institucional, tendo Hopwood (1983) como um dos pioneiros, a fim de descobrir novas facetas e aspectos do processo contábil. No Brasil, interessantíssimo exemplo tem sido o do Metrô de São Paulo que procura identificar todos os benefícios sociais por ele trazidos, como economia de combustível, redução da poluição etc., cotejando-os com o seu resultado contábil normalmente negativo, procurando evidenciar um saldo positivo.

Segundo Meyer e Rowan (1992), a institucionalização é um processo mediante o qual valores sociais (práticas, crenças, obrigações) assumem a condição de regra no pensamento e na ação dos indivíduos, quer estejam aglutinados numa organização ou dispersos na sociedade de forma geral. Assim, nem sempre as pessoas e as organizações se comportam de forma absolutamente racional. Mas, adotam esse ou aquele procedimento por considerá-lo melhor, mais adequado, mais justo, mais legítimo socialmente, mais "respeitável" etc. No fundo, essa nova visão traz conceitos e elementos cognitivos da Sociologia, abrindo novas fronteiras para a pesquisa contábil, pois se parte da admissão de que o mundo das empresas, dos agentes econômicos, da Contabilidade, não é totalmente racional ou movido apenas por desejos de lucro máximo a curto prazo e a qualquer custo. (Para um estudo mais aprofundado, veja o Capítulo 1 do livro "Teoria Avançada da Contabilidade", IUDíCIBUS e LOPES, 2004.). Essas visões sociais, sociológicas e institucionais abrem um vasto campo de investigação para a Contabilidade, e metodologias de pesquisa empírica podem perfeitamente ser utilizadas, como se faz em Sociologia e Psicologia.

\section{ABORDAGENS QUE JÁ SE CONSTITUEM EM TEORIAS}

As abordagens Normativa e Positiva contêm tal densidade e abrangência que, efetivamente, ga- 
nham o "status" de Teorias. Evidentemente, qualquer abordagem, as analisadas no tópico anterior e outras, (veja IUDíCIBUS, 2004), pode, no futuro, atingir a dimensão de teoria.

A teoria normativa, apoiada, preferencialmente, no método dedutivo, faz hipóteses sobre o universo contábil e deriva prescrições de como a Contabilidade deveria proceder para maximizar a utilidade da informação para os variados tipos de usuários. A teoria positiva foca aspectos mais restritos da fenomenologia contábil, estabelece hipóteses e testa, muitas vezes através de métodos quantitativos, mas nem sempre, tais hipóteses. Procura entender o mundo contábil como ele é, porque é assim e não como deveria ser. Já se tratou bastante, em livros, artigos e palestras, das diferenças entre as duas teorias e não se vai aprofundar o assunto aqui. Apenas se destaca que as duas formas de encarar a Contabilidade se transformaram em teorias, a primeira pela sua abrangência e pela lógica de sua derivação e a segunda (a positiva) pelas evidências, totalmente insuspeitadas algumas, que revela, após as hipóteses terem sido testadas.

É claro que a metodologia de preferência da teoria positiva é a indutiva. Os autores que preferem a abordagem (teoria) positiva são bastante críticos com relação à normativa. Os seguidores dessa última, usualmente, são mais ávidos em conhecer as vantagens do positivismo do que em criticá-lo. Talvez por ser uma abordagem (teoria) que somente iniciou seu desenvolvimento na década de 60, sendo, ainda, relativamente recente, o positivismo contábil (não confundir com o positivismo de A. Comte, filósofo) ainda se constitui em algo "excêntrico", para a maior parte dos pensadores contábeis, no Brasil.

O grande defeito da abordagem (teoria) normativa é que é preciso muito tempo e experimentação para verificar se as prescrições deram certo, no mundo real da Contabilidade. O risco é muito grande, pois depende das premissas serem válidas e das normas vencerem o teste da realidade.

A limitação da abordagem (teoria) positiva é a dificuldade que se tem em traçar um elo entre as várias pesquisas e testes de hipóteses, no sentido evolutivo. Na primeira vez que se lê um texto positivo, tem-se a impressão de que se trata de uma série de pesquisas, sem poder se estabelecer uma ordem e uma seqüência lógicas. Evidentemente, classificações dos tipos de pesquisa podem ser feitas, como: pesquisas de mercado de capitais, pesquisas de value-relevance, pesquisas de gerenciamento de resultados etc., mas, ainda assim, para o pesquisador iniciante, é difícil estabelecer uma visão de conjunto.

Pensa-se que, com a evolução e aprimoramento da teoria positiva e sua experimentação, num período não muito longo de tempo surgirá uma forma de entender melhor o entrelaçamento entre as pesquisas e de formar uma teoria geral. De qualquer maneira, finalmente começa a se notar no Brasil a tendência do incremento do número de pesquisas, trabalhos e dissertações e teses que utilizam metodologias empíricas, em contraste com a absoluta predominância de trabalhos descritivos, que caracterizou a produção literária contábil até recentemente. Para um maior aprofundamento no estudo da epistemologia contábil, veja-se Theóphilo (2004).

\section{DO CUSTO HISTÓRICO AO VALOR: A DIFÍCIL TRAVESSIA}

Quando se cristalizou a excelência do "método" contábil para registro, ficou visível a viabilidade de ele permitir relatos ou relatórios a partir dos quais análises de desempenho ficariam mais robustas - entenda-se aqui tais análises tanto do passado quanto prospectivas. Essa a gênese da Contabilidade, como meio de informação, e sua característica de disciplina utilitária: primeiro, aos interessados em desempenhos pretéritos (autoridades tributárias para arrecadar, acionistas para esperar dividendos) a Contabilidade acudia e acode com métricas inteligíveis. Aos demais, ela se presta a mostrar como foi o passado eminentemente como base para estimar como será o futuro. $O$ caráter preditivo da Contabilidade alcançou tal relevância que no mundo dos mercados de capitais, é pacífico o entendimento de que demonstrações contábeis servem, primária e fundamentalmente, para auxiliar a prever fluxos futuros de caixa. É o ato de conhecer a "causa mortis" destinando-se a pesquisar remédios que a evitem no futuro.

Nesse contexto, ao evoluir a Contabilidade vestiu, desde sua origem, as sandálias da humildade e, tendo em vista que o modelo contábil trata, preferencialmente, de transações realizadas e seu efeito no patrimônio, o valor de transação tem sido o paradigma central para a mensuração. A Contabilidade é um excelente meio para se apurar o resultado e efeitos no patrimônio da entidade de suas operações com o mundo exterior. Apesar dos avanços da Contabilidade Gerencial e de Custos, ainda há dificuldades para alocar tal resultado às divisões internas da entidade, mesmo as operacionais. Mais ainda para as de serviços. Mas, é indiscutível a efetividade do modelo, dentro de suas limitações. Com a evolução das formas organizacionais, levando a grandes conglomerados, os contadores responderam com a técnica de consolidação de balanços, um grande passo. Mas, note-se que a essência é sempre a de evidenciar o resultado do grupo 


\section{de entidades com relação às transações com o mundo fora do conglomerado.}

Talvez que, se não tivesse sido inventado o método das partidas dobradas, se a Contabilidade, com dificuldades enormes, tivesse continuado a ser apenas o levantamento periódico de inventários de bens, direitos e obrigações (balanços patrimoniais), a avaliação dos elementos patrimoniais teria sido, desde o início, a valores de mercado, atuais, pelo menos na data de cada avaliação. Não existindo a sistemática de acumulação propiciada pelas partidas dobradas, provavelmente, o contador, ao levantar o balanço, avaliaria seus elementos patrimoniais por um valor mais atualizado possível. Mas, essa é apenas uma hipótese de impossível comprovação. $O$ fato é que as partidas dobradas, pela tempestividade e eficiência com que permitiram o registro das operações (com as fases posteriores de balancetes, ajustes, balanços etc.), privilegiaram o valor de transação (custo histórico). O valor histórico para determinados elementos patrimoniais (estoques e imobilizado, principalmente), por significar a retenção, na memória, do valor do caixa despendido na sua aquisição, a fim de se descarregar esse fluxo contra o da entrada propiciado pelo reconhecimento da receita também parece explicar fortemente a manutenção dessa base de registro. Veja-se Martins (1999; 2001).

Apesar de, ao longo da história, terem se verificado, em vários países, surtos inflacionários de dimensões às vezes extraordinárias (como na Alemanha, por volta da Primeira Grande Guerra, no Brasil, nas décadas de 80/90 e em muitos outros países, inclusive nos EUA, na década de 70, com taxas, para aquele país, altas), a profissão contábil foi relativamente lenta em responder com técnicas e modelos compensatórios, talvez com exceção do Brasil e de poucos outros paises (como Argentina, Chile e Israel). De fato, desde 1958, o Brasil institui a reavaliação de ativos fixos e, em seguida, adotou vários modelos de correção, culminando com a Correção Monetária Integral, em 1987. Abruptamente, em meados da década de 90, o Governo Federal extinguiu a correção monetária, como se a inflação tivesse desaparecido completamente de nosso cenário econômico.

Os pesquisadores e acadêmicos, entretanto, dedicaram-se, desde os primórdios dos surtos inflacionários, a moldar modelos compensatórios. Antigos trabalhos acadêmicos com relação ao custo histórico corrigido pela inflação geral remontam a 1919, com E. Schmalenbach e F. Schmidt (este mais em relação ao custo de reposição) na Alemanha, década de $20 \mathrm{com}$ G. Zappa (GALASSI e MATTESSICH, 2004; MATTESSICH e KUPPER, 2003), culminando, em 1936, com a extraordinária obra de Sweeney. Não se contará, aqui, sobre a cronologia de trabalhos acadêmicos de autores da USP e outros de outros centros de pesquisa no Brasil, por ser demasiado conhecida de nossos estudiosos.

É forçoso reconhecer, entretanto, que, mesmo entre alguns acadêmicos, tratou-se mais de dar respostas parciais e espaçadas no tempo para problemas emergenciais, do que de erigir uma verdadeira teoria da avaliação patrimonial a valores econômicos, de forma estruturada e integral, com exceção do notável trabalho de Edwards e Bell (1961). Trabalhos nessa linha, principalmente na trilha do custo de reposição, transformaram-se em marcos no Brasil, como o primeiro dos autores deste ensaio, ludícibus (1966) e Szüster (1985).

Estranhamente, por volta de meados a fins dos anos 90, e anos iniciais do Século XXI, foram os órgãos reguladores internacionais, como o FASB e IASB, a dar o toque de avançar, instituindo, limitadamente é verdade, a avaliação a valores de mercado e, finalmente, o fair value, enquanto os acadêmicos ficavam extasiados ao contemplar, como novos Narcisos, no espelho das vaidades, suas antigas imagens, distorcidas por modelos parciais de correção. Rara exceção, nesse contexto, é a obra da FIPECAFI, organizada por Eliseu Martins (2001), intitulada "Avaliação de Empresas: Da Mensuração Contábil à Econômica", editada pela Atlas.

Os contadores têm sido criticados por providências que "deveriam" ter tomado, segundo os críticos, mas que, na verdade, representariam um excesso de subjetivismo, talvez não totalmente responsável, como tentar inserir no ativo o valor do Capital Intelectual, ou do Goodwill criado internamente, conceitos reconhecidamente importantes, mas ainda pouco suscetíveis de uma avaliação que, embora sempre subjetiva, tivesse um mínimo de sustentação. Entretanto, nada impediria, a não ser considerações de custo/benefício, de apresentar tais avaliações em quadros suplementares, indicando com clareza os critérios utilizados. Existem, todavia, tópicos mais urgentes a serem atacados no Brasil como Relatórios por Segmentos, Resultado de Operações Descontinuadas, Leasing, Concessões e outros para os quais existem encaminhamentos parciais.

A travessia do custo histórico para o valor, como detalhada em trabalho anterior por ludícibus (1998), não é isenta de dificuldades e perigos. Acadêmicos e profissionais divergem sobre o que seria exatamente valor para a Contabilidade. Será um custo de reposição calculado? Ou um valor de cotação de mercado (de compra ou de venda?). Ou o valor presente dos fluxos de caixa que um ativo é capaz de gerar? Um ativo isoladamente, ou em conjugação com outros e outros fatores? A definição de Fair Value, ou seja, “... importância pela qual um 
ativo poderia ser transacionado entre um comprador disposto e conhecedor do assunto e um vendedor também disposto e conhecedor do assunto, em uma transação sem favorecimento" (IUDÍCIBUS, MARION e PEREIRA, 2003), também é repleta de dificuldades, pois, no fundo, dever-se-ia reproduzir, já passado certo tempo da transação original, a condição da própria transação, até expurgada de eventuais situações de força de barganha por parte do vendedor ou comprador, tendo em vista sua posição no mercado. Entretanto, não se vê como deixar de enfrentar o desafio. A Contabilidade repousou por longo tempo, longo demais, na auto-satisfação de sua "objetividade" presumida, como se, mesmo avaliando a valores de custo histórico, as cifras contábeis, exceto algumas, não fossem meras estimativas. Já que se trata de aproximações, está na hora de assumir, de vez, o subjetivismo responsável, de que falam ludícibus e Carvalho (2001).

\section{O PROBLEMA DAS LINHAS DOUTRINÁRIAS}

No Brasil, limitadamente ao campo acadêmico, ainda se discute que "escola" de Contabilidade deveria ser seguida. A Européia Continental, primordialmente Italiana, considerada pelos seus seguidores como a única capaz de atribuir conteúdo conceitual e filosófico à essa disciplina, ou a "escola" denominada, por brevidade, de "anglo-saxônica", e duramente criticada pelos "supporters" da primeira (mas abraçada completamente pelo IASB - International Accounting Standards Board, pela União Européia para suas companhias abertas (o que inclui países latinos e germânicos) a partir de 2005, e em direção à qual caminham a China, o Japão, o México, e, tímida e tentativamente, o Brasil, entre outros), qualificando-a como privada de densidade teórica e apressadamente classificada e taxada de "empírica". Interessante que se destitui ao empirismo qualquer conotação conceitual, como se os empíricos tivessem sido um bando de aventureiros e de desprovidos de razão, quando, na verdade, se tratou de uma corrente filosófica extremamente nobre que baseava e baseia suas visões do mundo na evidência e na constatação.

Considera-se que, no estágio atual da evolução da Contabilidade, com a globalização e a convergência internacional da regulação, tal acalorada discussão sobre as duas visões da Contabilidade perde parte de seu significado na prática, sendo certo, todavia, que ambas são dignas (pelo menos para os "scholars"), de estudo e de meditação. O mais importante, mesmo nesse exercício teórico, é buscar os pontos de convergência, sempre se privilegiando o usuário da informação contábil. Estudiosos de grande capacidade pertencem ou pertenceram a uma dessas orientações, obviamente com muitos ajustes finos. Diga-se que, usualmente, são os que vestem a camisa de uma escola a classificar os outros no outro time, "arqui-rival". Não se pode deixar de comentar, todavia, que, na opinião destes ensaístas, a forma de encarar a Contabilidade, simplesmente taxada de "anglo", encontra muito mais amparo e seguidores nas empresas de ponta e entre os profissionais mais atualizados num número cada vez maior de países. Na verdade, na prática, possivelmente nem se cogitaria da aplicação das normas emanadas da "outra" escola, mesmo que existissem. Academicamente, entretanto, as discussões sérias e profundas são sempre bem-vindas, sempre no pressuposto do respeito intelectual e pessoal em face das divergências de visão.

\section{O ENIGMA PERMANECE: AFINAL, O QUE É CONTABILIDADE?}

Não haverá relato da evolução passada da Contabilidade, por mais completo e pormenorizado que possa ser, que apresente o retrato perfeito e integral do que é e, mais ainda, do que possa vir a ser essa disciplina. Uma fotografia de uma paisagem ou de qualquer ser ou objeto transmite uma visualização instantânea do ser; uma série de retratos, tirados em datas e épocas diferentes, traduzem a evolução. Da análise dessa evolução podem-se extrair algumas generalizações, com muito cuidado, mas a integralidade do ser e sua tendência no futuro se apresentam como enigmáticos.

É confortante poder expressar as dimensões atuais da Contabilidade como uma forma eficaz de avaliação de desempenho econômico e financeiro (e social) de entidades e gestores; como insumo essencial para a tomada de decisões econômico-financeiras; como instrumento de accountability eficiente de qualquer gestor de recursos perante a sociedade. Isso é um fato. Acredita-se que a Contabilidade possa evoluir muito mais, mas a dimensão e a direção dessa evolução dependem de muitos fatores institucionais, econômicos e sociais.

Querer, assim, prognosticar o que a Contabilidade possa vir a ser é querer prever o que a sociedade humana será, no futuro. Afinal, Melis (1950) expressou da forma mais feliz a complexidade do enigma: "A história da contabilidade confunde-se com a história da própria civilização!". 


\section{REFERÊNCIAS BIBLIOGRÁFICAS}

ANTHONY, R. N. Management Accounting. Homewood Irwin, 1966. ANTUNES, M. T. P.. Contribuição ao Entendimento e Mensuração do Capital Intelectual. 1999. Dissertação (Mestrado em Ciências Contábeis. Área de concentração: Controladoria e Contabilidade). Faculdade de Economia, Administração e Contabilidade da Universidade de São Paulo, São Paulo.

BALL, R.; BROWN, P.. An Empirical Evaluation of Accounting Numbers. Journal of Accounting Research, v. 7, Out. 1968.

BEAVER, W. The Information content of annual earnings announcement. Journal of Accounting Research, v. 6, suplemento, 1968.

DEMSKI, J.. Uncertainty and Evaluation Based on Controllable Performance. Journal of Accounting Research X (autumn 1976), 230-45.

EDWARDS, E.; BELL, P.. The Theory and Measurement of Business Income. University of California Press, 1961.

GALASSI, G.; MATTESSICH, R.. Italian Accounting Research in the First Half of the 20th Century. Review of Accounting \& Finance, vol. 3, 2004, p. 62.

HENDRIKSEN, E. S.; VAN BREDA, M. F.. Teoria da Contabilidade. São Paulo: Atlas, 1999.

HOPWOOD, A.G.. On trying to study accounting in the contexts in which it operates. Accounting, Organizations and Society, 1983, 8: 287-305.

IUDICIBUS, S.. Contribuição à Teoria dos Ajustamentos Contábeis. 1966. (Tese de Doutoramento) Faculdade de Economia, Administração e Contabilidade, Universidade de São Paulo, são Paulo.

Conhecimento, Ciência, Metodologias Científicas e Contabilidade, Parte II. Revista Brasileira de Contabilidade, MarçoAbril de 1998.

2004.

Teoria da Contabilidade. $7^{\text {a }}$ ed., São Paulo: Atlas,

; CARVALHO, L. N.. Por que Devemos Ousar em Contabilidade. Boletim do IBRACON, Maio de 2001.

; LOPES, A.. De Volta para o Futuro: Óbito Presumido e Outros Mitos que Habitam o Castelo da Contabilidade. UnB Contábil, 2002, 59.

; LOPES, A. B.. Teoria Avançada da Contabilidade. São Paulo: Atlas, 2004.

; MARION, J. C.; PEREIRA, E.. Dicionário de Termos de Contabilidade. $2^{\mathrm{a}}$ ed., São Paulo: Atlas, 2003.

JENNERGREN, L. P.. On the Design of Incentives in Business Firms-A Survey of Some Research. Management Science XXV (February 1980), 180-200.

JENSEN, M. C.; MECKLING, W. H.. Theory of the firm: managerial behavior, agency costs and ownership structure. Journal of Financial Economics, v. 3, Out. 1976.

KAM, V. Accounting Theory. New York: John Wiley \& Sons, 1990.
LOPES, A. B.. A Informação Contábil e o Mercado de Capitais. São Paulo: Thomson, 2002.

MARTINS, E.. Uma Geral na Contabilidade. Seleções ATC, COAD, 1988. e 2a. Convenção de Contabilidade do Rio Grande do Sul, Canela, agosto/1988.

Contabilidade versus Fluxo de Caixa. Caderno de Estudos EAC/FIPECAFI, v. 11, n. 20, janeiro/abril-1999.

Contabilidade versus Fluxo de Caixa. $I O B$ - Caderno de Temática Contábil, n. 20, 3a. semana, maio-2000.

(org.) Avaliação de Empresas: Da Mensuração Contábil à Econômica. São Paulo: Atlas, 2001.

; LISBOA, L. P.. Ensaio Sobre Cultura e Diversidade Contábil. Revista Brasileira de Contabilidade, $\mathrm{n}^{\circ} 152$, ano XXXIV, Março-Abril, 2005.

MATTESSICH, R.; KUPPER, H.U.. Accounting research in the German language area-first half of the 20th century. Review of Accounting \& Finance, vol. 2, 2003, p. 106.

MELIS, F. Storia della Ragioneria. Bologna: Dott. Cesare Zuffi, 1950.

MEYER, J. W.; ROWAN, B.. Institutionalized organizations: formal structure as myth and ceremony. London: Sage, 1992.

RIBEIRO, M. S.. Contabilidade e Meio Ambiente. 1992. Dissertação. (Mestrado em Ciências Contábeis. Área de concentração: Controladoria e Contabilidade) Faculdade de Economia, Administração e Contabilidade, Universidade de São Paulo, São Paulo.

Custeio das Atividades de Natureza Ambiental. 1998. Tese (Doutorado em Ciências Contábeis. Área de concentração: Controladoria e Contabilidade). Faculdade de Economia, Administração e Contabilidade, Universidade de São Paulo, São Paulo.

ROSS, S.. The Economic Theory of Agency: The Principal's Problem. American Economic Review, LXIII (March 1973), 134-39.

SWEENEY, J.. Stabilized Accounting. 1936.

SZÜSTER, N.. Análise do Lucro Passível de Distribuição. 1985. Tese (Doutorado em Ciências Contábeis. Área de Concentração: Controladoria e Contabilidade). Faculdade de Economia, Administração e Contabilidade, Universidade de São Paulo, São Paulo.

THEÓPHILO, C. R.. Pesquisa em Contabilidade no Brasil: Uma Análise Crítico-Epistemológica. 2004. Tese (Doutorado em Ciências Contábeis. Área de concentração: Controladoria e Contabilidade). Faculdade de Economia, Administração e Contabilidade, Universidade de São Paulo, São Paulo.

TINOCO, J. E. P.. Balanço Social: uma abordagem da transparência e da responsabilidade pública das organizações. São Paulo: Atlas, 2001.

WILSON, R.. The Theory of Syndicates. Econometrica XXXVI (January 1968), 119-32.

\section{NOTA:}

Endereço dos autores:

\section{FEA-USP}

Av. Prof. Luciano Gualberto, 908

Cidade Universitária

São Paulo - SP

05508-900 